\title{
Analyzing Spatial Drivers in Quantitative Conflict Studies: The Potential and Challenges of Geographic Information Systems
}

\author{
Nathalie Stephenne, Clementine Burnley, and Daniele Ehrlich \\ Institute for the Protection and Security of the Citizen, Joint Research Centre, European \\ Commission
}

\begin{abstract}
The objective of this literature review is to understand where Graphical Information Systems (GIS) can be useful to address security issues and how it has been used until now. While the geographic drivers of territorial conflicts have been extensively described by a number of political studies, the quantitative analysis of these drivers is quite new. This study traces an evolution from conceptual research to quantitative development. It then discusses the advantages and challenges of applying new geographic techniques to analyze spatial drivers of conflict. We identify the main spatial components in conflict and security, the existing types of information/data and the quantitative methods used. We describe the spatial component of security by looking at: (i) the main sociopolitical concepts linked to territory, (ii) the kind of geographic concepts linked to territory, (iii) measures used to describe such geographic concepts; and (iv) the issues raised in any attempt to integrate geographic concepts into a GIS. We conclude that GIS tools can be useful in the analysis of civil disputes, particularly where subnational level data exists. This paper shows that spatial processing tools in GIS allow us to represent some spatial components and to address new issues such as the fuzzy complexity of border permeability.
\end{abstract}

Political and social scientists have quantitatively analyzed the drivers of conflicts in a large number of studies. Geographic components and territorial concepts have emerged as important drivers in interstate disputes. However, geographic components are rarely defined or measured with the same technique. This study reviews geographic and territorial concepts, associated data sets and analysis methods. The study objective is to represent geographic and territorial concepts with Geographic Information Systems (GIS). The paper describes the challenges and potential opportunities for creating an integrated GIS model of security.

A GIS uses digital data to represent space and time in an abstract model of reality. Reality is highly complex; digital models are simplifications that can help us to better understand reality using a specific set of assumptions. GIS software can integrate disparate data sets together in a common model. It can thus be seen as an ideal instrument to develop a multidisciplinary understanding of conflicts.

The use of GIS technology is currently specific to traditional science and "practitioners" in land use, urban planning, transportation, and environmental 
studies (Longley, Goodchild, Maguire, and Rhind 1999; Liu and Zhu 2004). A new use of this technique in security matters should ideally be based on close collaboration between political and social scientists and technology researchers. Unfortunately, this collaboration is unusual, even though security policymakers have called for improved dialog between social science and technology researchers (Pullinger 2006).

In the field of geography, social discourses on GIS have criticized ideas of virtual space, issues of data manipulation, and the power of GIS when used as an "instrument of policymaking" (Pickles 1995; Curry 1999; Schuurman 2000; Kwan 2002). Schuurman and Pratt (2002) note that these epistemological arguments seem not to be grounded in practice of using the tool. For their part, GIS practitioners do not completely accept the sociopolitical arguments from the field of international relations. At root, this remains a debate between quantitative and qualitative researchers. Despite their traditional GIS background, the authors of this paper propose an alternative to the usual bottom-up and data-driven approach. An integrated GIS model can be based on the conceptual framework provided by sociopolitical conflict studies. GIS technologies would then provide a means to test some existing geopolitical theories.

In this paper, the spatial concepts identified in a broad conflict literature review are categorized and compared in four separate tables to identify (i) spatial components in security and conflict, (ii) necessary information/data, and (iii) quantitative methods. Identification of spatial components, data, and methods is an essential first step in building an integrated GIS for security issues.

\section{Evolution of Spatial Concepts in Security Studies}

The concept of security has evolved over time within two main schools of thought: realist security and human security. Until the end of the Cold War, the realist security concept was related to the protection of state sovereignty over a spatial territory within delimited borders. Conflict threats came from neighbor or proximate states, "armed foreigners," who challenged state sovereignty (Del Rosso 1995). By contrast, the human security concept addresses threats occurring to the individual-the object whose security is at stake-as well as threats occurring at a higher scale (i.e. state level). In both schools of thought, security has a spatial component which is addressed in geographic sciences (Burnley, Stephenne, and Agüera-Cabo 2008).

The field of geography dealt with security in two different ways before and after World War II. Security was first used to support actions in external relations and then to explain causes and development of conflicts. Until World War II, geographic knowledge was largely used in the military expansion projects of colonial powers (Mamadouh 2005; Foster 2006). After World War II geographers started to conceptualize and analyze the causes of conflicts in the emerging disciplines of political geography, international relations and geopolitics (Megoran 2004). In a number of recent studies geographic analysis is carried out using information technologies and especially GIS.

An information system is a computer-based set of software modules that interact with a database. The system processes and transforms digital data into information that is meaningful to a set of users. Information systems handling geographic data are referred to as GIS. These computer systems combine spatial data processing tools including data collection and management systems, geo-processing technology, and tools for manipulation and visualization of outputs. Spatial research in GIS has progressively revolutionized the manipulation of geographic information in social sciences (Anselin 1999). GIS are starting to be used in political sciences for managing politically relevant geo-information, for the spatial representation of political processes and for the quantitative analysis of these processes. 
This section describes the evolution of spatial quantitative analysis of conflict in three sections. The section entitled Spatial Concepts in Security describes the spatial concepts of security which are embedded in "essentially contested concepts" (Newman 2000; Ackleson 2003; Agnew, Mitchell, and Toal 2003). The section entitled Geographic Quantitative Measures lists quantitative spatial measures used to describe sociopolitical concepts and the section entitled Issues of Integrating Space and Security outlines the challenges of integrating security and space into a homogenous frame such as a GIS.

\section{Spatial Concepts in Security}

The spatial concept of "territory" is intrinsically linked to "power" and "sovereignty" within a political community enclosed by "borders" (Paasi 2003). The definition of territories is therefore a sociopolitical and cultural construction of space. This construction refers to our identity and to the difference between "us" and the "others" (Schack 2000). However, individuals may progressively attach less importance to geographic space due to new global and transnational dynamics, and exposure to global information. The perceived needs for territorial control may diminish, endangering the concept of sovereignty as we know it today (Edwards 2005). Table 1 presents the most widely used definition of "territory," "power" and "sovereignty" including the evolution of these terms with recent changes in geopolitical order.

While these concepts have been extensively discussed in sociopolitical papers, only a limited number of sociopolitical studies have addressed security issues in a quantitative way. The main quantitative analysis of security has been performed in conflict studies, using global data sets built by four projects: Correlates of War, Militarized Interstate Disputes (MID), International Crisis Behavior, and the State Failure project.

\section{Geographic Quantitative Measures}

Space and distance are probably the main geographic concepts used in security research. Proximity, geographic opportunity (Goertz and Diehl 1992; Vasquez 1993; Lemke 1995; Gleditsch 2002), and the nature of borders between contiguous states (Starr and Most 1976) are the most studied geographic concepts in security. Table 2 presents spatial quantitative studies of conflict. The table identifies for each study both the spatial concepts and the methods used to integrate these spatial concepts in explanations of conflict. The earlier papers pioneered

TABLE 1. Definitions of the Three Main Spatial Concepts of Security in Realist and Human Security Paradigms

\begin{tabular}{llll}
\hline $\begin{array}{l}\text { Spatial political } \\
\text { concepts }\end{array}$ & Definition & $\begin{array}{l}\text { Realist security } \\
\text { paradigm }\end{array}$ & $\begin{array}{l}\text { Changes to security } \\
\text { paradigm with } \\
\text { human security }\end{array}$ \\
\hline Territory & $\begin{array}{c}\text { Portion of space claimed } \\
\text { by individuals, social } \\
\text { groups, or institutions } \\
\text { Recognized authority } \\
\text { Sovereignty }\end{array}$ & Nation/state & $\begin{array}{c}\text { Various levels of } \\
\text { territorial and } \\
\text { nonterritorial actors } \\
\text { Individuals mediated by } \\
\text { various modes of } \\
\text { communication }\end{array}$ \\
& $\begin{array}{c}\text { Neutral lines that are } \\
\text { located between power } \\
\text { structures (Paasi 2003) }\end{array}$ & $\begin{array}{c}\text { Lines that enclose } \\
\text { state territories }\end{array}$ & $\begin{array}{c}\text { Permeable borders and } \\
\text { transboundary } \\
\text { collaboration }\end{array}$ \\
\hline
\end{tabular}


TABLE 2. Quantitative Conflict Studies Introducing Geographic Concepts as Drivers of Conflict

\begin{tabular}{|c|c|c|c|}
\hline Author & Subject (short title) & $\begin{array}{l}\text { Geographic and } \\
\text { security concepts }\end{array}$ & Measure/method \\
\hline $\begin{array}{l}\text { Richardson } \\
\text { (1960) }\end{array}$ & $\begin{array}{l}\text { Statistics of deadly } \\
\text { quarrels/contiguity }\end{array}$ & $\begin{array}{l}\text { Clustering of quarrels/test } \\
\text { of boundary effect } \\
\text { (contiguity) }\end{array}$ & $\begin{array}{l}\text { Population grid cells/ } \\
\text { homoplaty/ } \\
\text { compactness/Poisson } \\
\text { law of wars }\end{array}$ \\
\hline Wesley (1962) & $\begin{array}{l}\text { Frequency of wars and } \\
\text { geographical } \\
\text { opportunity }\end{array}$ & $\begin{array}{l}\text { Wars frequency/ } \\
\text { contiguity/proximity }\end{array}$ & $\begin{array}{l}\text { Length of border/ } \\
\text { population cells }\end{array}$ \\
\hline Boulding (1962) & Conflict and defense & $\begin{array}{l}\text { Distance following the log } \\
\text { relation of Zipf (1946) }\end{array}$ & $\begin{array}{l}\text { National strength/loss } \\
\text { of strength gradient/ } \\
\text { cost function of influence }\end{array}$ \\
\hline $\begin{array}{l}\text { Starr and Most } \\
\text { (1976) }\end{array}$ & $\begin{array}{l}\text { Borders in } \\
\text { international } \\
\text { dimensions }\end{array}$ & Contiguity/type of border & $\begin{array}{l}\text { Categorization of } \\
\text { international borders } \\
\text { data set }\end{array}$ \\
\hline $\begin{array}{l}\text { Goertz and Diehl } \\
\text { (1992) }\end{array}$ & $\begin{array}{l}\text { Territorial changes } \\
\text { in conflicts }\end{array}$ & $\begin{array}{l}\text { De-colonialism and } \\
\text { territory exchange } \\
\text { models }\end{array}$ & $\begin{array}{l}\text { Factor statistical } \\
\text { modeling technique }\end{array}$ \\
\hline Vasquez (1993) & The war puzzle & $\begin{array}{l}\text { Territory/ } \\
\text { contiguity/ } \\
\text { neighbor/borders }\end{array}$ & $\begin{array}{l}\text { Clustering of } \\
\text { neighbors-distance } \\
\text { between capitals/ } \\
\text { technology/number } \\
\text { of wars }\end{array}$ \\
\hline $\begin{array}{l}\text { Bueno de } \\
\text { Mesquita } \\
\text { and Lalman } \\
\text { (1992); Lemke } \\
\text { (1995) }\end{array}$ & Tyranny of distance & Contiguous dyads & $\begin{array}{l}\text { Distance between } \\
\text { disputants-number } \\
\text { of miles per day varying } \\
\text { with terrain and } \\
\text { technology }\end{array}$ \\
\hline Senese (1999) & Geographical proximity & $\begin{array}{l}\text { Proximity/territorial } \\
\text { disputes }\end{array}$ & $\begin{array}{l}\text { Logit/probit/cluster } \\
\text { of countries }\end{array}$ \\
\hline Vanzo (1999) & $\begin{array}{l}\text { Border configuration } \\
\text { and conflict }\end{array}$ & $\begin{array}{l}\text { Territorial compactness or } \\
\text { border shape as strategy } \\
\text { of war }\end{array}$ & $\begin{array}{l}\text { Measures of } \\
\text { compactness/historical } \\
\text { maps for evidences }\end{array}$ \\
\hline Huth (2000) & $\begin{array}{l}\text { Empirical analysis in } \\
\text { conflicts }\end{array}$ & $\begin{array}{l}\text { Geographic and territorial } \\
\text { assumptions in disputes }\end{array}$ & $\begin{array}{l}\text { Statistical multivariate } \\
\text { regression }\end{array}$ \\
\hline $\begin{array}{l}\text { Tir and } \\
\text { Diehl (2002) }\end{array}$ & $\begin{array}{l}\text { Geographic dimension } \\
\text { of enduring rivalries }\end{array}$ & $\begin{array}{l}\text { Conflict over } \\
\text { territory/proximity as } \\
\text { facilitating factor }\end{array}$ & $\begin{array}{l}\text { MID probit statistical } \\
\text { model/Ordinary Least } \\
\text { Squares regression }\end{array}$ \\
\hline $\begin{array}{l}\text { Gleditsch and } \\
\text { Ward (2001) }\end{array}$ & $\begin{array}{l}\text { Minimum-distance } \\
\text { data set }\end{array}$ & $\begin{array}{l}\text { Proximity pairs of } \\
\text { states/varying thresholds }\end{array}$ & $\begin{array}{l}\text { Statistical multivariate } \\
\text { regression }\end{array}$ \\
\hline $\begin{array}{l}\text { Starr and } \\
\text { Lindborg (2003) }\end{array}$ & $\begin{array}{l}\text { Democratic Dominoes } \\
\text { revisited }\end{array}$ & $\begin{array}{l}\text { Diffusion of } \\
\text { democracy/socialization } \\
\text { patterns (Deutsch)/ } \\
\text { clustering }\end{array}$ & $\begin{array}{l}\text { Poisson/Hazard/ } \\
\text { regionalization }\end{array}$ \\
\hline $\begin{array}{l}\text { Starr and } \\
\text { Thomas (2002) }\end{array}$ & $\begin{array}{l}\text { Comparing contiguous } \\
\text { borders }\end{array}$ & $\begin{array}{l}\text { Territorial } \\
\text { contiguity/nature of } \\
\text { borders/democracy }\end{array}$ & $\begin{array}{l}\text { MID data/chi-squar } \\
\text { ed/nature of } \\
\text { borders/GIS }\end{array}$ \\
\hline $\begin{array}{l}\text { Wood and } \\
\text { Milefsky (2002) }\end{array}$ & $\begin{array}{r}\text { Territory and } \\
\text { negotiations }\end{array}$ & $\begin{array}{l}\text { Definition of border } \\
\text { porosity based on } \\
\text { geographic } \\
\text { factors/changes in time }\end{array}$ & Geographic data set/GIS \\
\hline $\begin{array}{l}\text { Buhaug and } \\
\text { Gates (2002) }\end{array}$ & $\begin{array}{l}\text { Geography of civil } \\
\text { wars }\end{array}$ & $\begin{array}{l}\text { Mineral resources/ } \\
\text { border/geographic } \\
\text { variables as territory }\end{array}$ & $\begin{array}{l}\text { Statistical multivariate } \\
\text { regression }\end{array}$ \\
\hline $\begin{array}{l}\text { Toset et al. } \\
(2000)\end{array}$ & Shared rivers & $\begin{array}{l}\text { Contiguity with rivers as } \\
\text { shared borders }\end{array}$ & $\begin{array}{l}\text { Statistical multivariate } \\
\text { regression }\end{array}$ \\
\hline
\end{tabular}

Notes: MID, Militarized Interstate Disputes; GIS, Geographic Information Systems. 
spatial research into conflict while later papers pointed out the interest of using GIS techniques to measure spatial dimensions of conflict.

The earliest studies addressed the shape of the territory. Richardson (1960) created one of the first data sets of conflicts and defined clusters of contiguous countries to explain the probability of war. He empirically tested a topological theory of territorial compactness to represent continuously the distance between population centroids. The compactness factor as a reason for conflict has been further studied by Vanzo (1999).

The length and number of shared borders quantify contiguity and proximity between two contiguous countries. Proximity increases the opportunity of interactions, called "geographic opportunity" by Wesley (1962). George Kingsley Zipf (1946) expressed the "principle of the least effort" in defining neighboring countries' proximity. This principle measures potential movement flows from one point to the other in a power law of distance. A similar log relation of space is used by Boulding (1962) to define the loss of strength gradient, a cost-space function that draws a sphere of influence/zone of viability specific to each country.

The above theories established a spatial dimension that has been more deeply studied in new geopolitics. Senese (1999) tested the proximity assumption in dispute escalation. Huth (2000) explained territorial disputes by using proximity and contiguity. Tir and Diehl (2002) provided arguments against the systematic use of geographic variables in the explanation of disputes or rivalries. Tir and Diehl (2002) maintain that most rivalries are not fought between neighbors but geography remains an essential factor in conflict escalation or in increasing the likelihood of conflict recurrence. They use the MID data set to show that while conflict density and rivalry development are influenced by land contiguity, rivalry severity is more a function of the disputed issues (i.e., territorial control) than of opportunity to fight (i.e. proximity). Starr and Lindborg (2003) called for more spatial analysis in political studies and addressed diffusion of democracy in international border studies. The concept of diffusion integrates both time and space.

The last group of authors envisages the potential of GIS to collect and integrate spatial data to improve the analysis of proximity. Gleditsch and Ward (2001) introduced a distance threshold in conflict data sets. Starr and Thomas (2002) distinguished contiguous/noncontiguous borders and tested the "nature" of the borders in wars. Their work is based on georeferenced data. GIS overlay functions make it possible to process spatial variables such as roads, slope, and population concentration to build indexes of opportunity and willingness attached to border segments. Wood and Milefsky (2002) proposed to use spatial visualization tools in local negotiation of border lines. Toset, Petter Gleditsch, and Hegre (2000) studied the effect of specific border characteristics such as joint rivers on the probability of armed disputes. These last studies identify a need for precise georeferenced data sets. Buhaug and Gates (2002) also argues in favor of the establishment of a GIS.

\section{Issues of Integrating Space and Security}

The methodological and theoretical challenges in introducing "space" in a security model are related to four separate aspects, which are: the definition of the spatial unit of analysis, the scale of this unit, the measure of distance, and the interaction of space and time. These aspects need to be taken into account while also retaining the full complexity of the sociopolitical theoretical framework.

The first challenge comes from the concept of "space" and the definition of spatial units to measure spatial characteristics. While sociopolitical events and processes vary across geographic space, the spatial area they cover is not 
unambiguously related to any given location on the Earth. Georeferencing processes and events to specific locations require us to establish indirect spatial links to spatial objects. In territorial studies, the spatial object is an area, a portion of earth, a territorial unit defined by enclosing borders. This spatial object is usually the country.

Technical and methodological issues such as spatial dependence and/or spatial heterogeneity are related to the delimitation of spatial units (Fischer 1999). Spatial dependence refers to the relationship between observations in two different locations. Spatial heterogeneity results from data that are not homogenous, which vary in size and shape (Getis 1999). While traditional statistical approaches assume independent observations, the field of spatial statistics is based on the assumption that nearby units are associated, or spatially auto-correlated. GIS is well suited for exploring and understanding such methodological issues. The GIS provides tools to address such methodological issues quantitatively. New techniques have been developed to measure, analyze and correct spatial dependence and heterogeneity. The most noteworthy techniques couple statistical packages and GIS software (Getis 1999; O'Loughlin and Witmer 2005).

The second challenge in introducing "space" in a security model pertains to the appropriate scale, which is related to the spatial unit of choice. Most conflict studies have been carried out at the global level, with the country as the unit of reference. Current conflicts are, by and large, civil conflicts (O'Loughlin 2005; Restrepo, Spagat, Reanier, and Suárez 2005). There is a growing consensus that to be able to study civil conflicts, variables should be available at subnational level (Hauge and Ellingsen 1998; Wood and Milefsky 2002; O'Loughlin 2003; Starr 2003). The study of civil war using country-level statistics is indeed "potentially flawed" (Buhaug and Rød 2005) because country-level statistics "dilute" the importance of determinants of violence that occur at local level. Unfortunately the collection of subnational data is done only for a limited number of regions (Mubareka, Al Khudhairy, Bonn, and Aoun 2005; Raleigh and Hegre 2005; Restrepo et al. 2005).

With "unit scale" the modifiable areal unit problem (MAUP) also needs to be addressed (Openshaw and Taylor 1981). Different aggregations of units can produce different distributions of zone characteristics even if there is no change in the underlying phenomena (Martin 1999). Aggregation of spatial units, or generalization, changes the results by changing the fitness of the relationship. The related concept of "ecological fallacy" states that relationships between variables which are observed at one level of aggregation may not hold at another level.

However, the unit scale challenge can also be seen as an opportunity. Analyzing phenomena at different scales can help researchers better to understand and characterize such phenomena. For example, through Exploratory Data Analysis (EDA) best outputs can be developed by visualizing alternatives. These multiple representations make it possible to test impacts of scale on outputs.

The third challenge in introducing "space" in a security model relates to the concept of proximity and its variation in time. This concept integrates a metric defining the distance between territorial units and the number of interrelations between locations. The interaction between actors is a function of distance but also of the kind of space in-between (nature of border).

Regardless of the metric used to measure distance, the interactions between units change over time. This poses a clear challenge in a quantitative assessment (Anselin 1999). The distinction between absolute and relative location helps to deal with some of these time changes and to deal with the influence of perceptual aspects. As an example, technology and a range of other human inventions are changing the meaning of space and time. This change has been described in the concept of a "shrinking world." Travel time or cost to reach a certain location depends on the actual cost but also on the ability of the potential traveler 


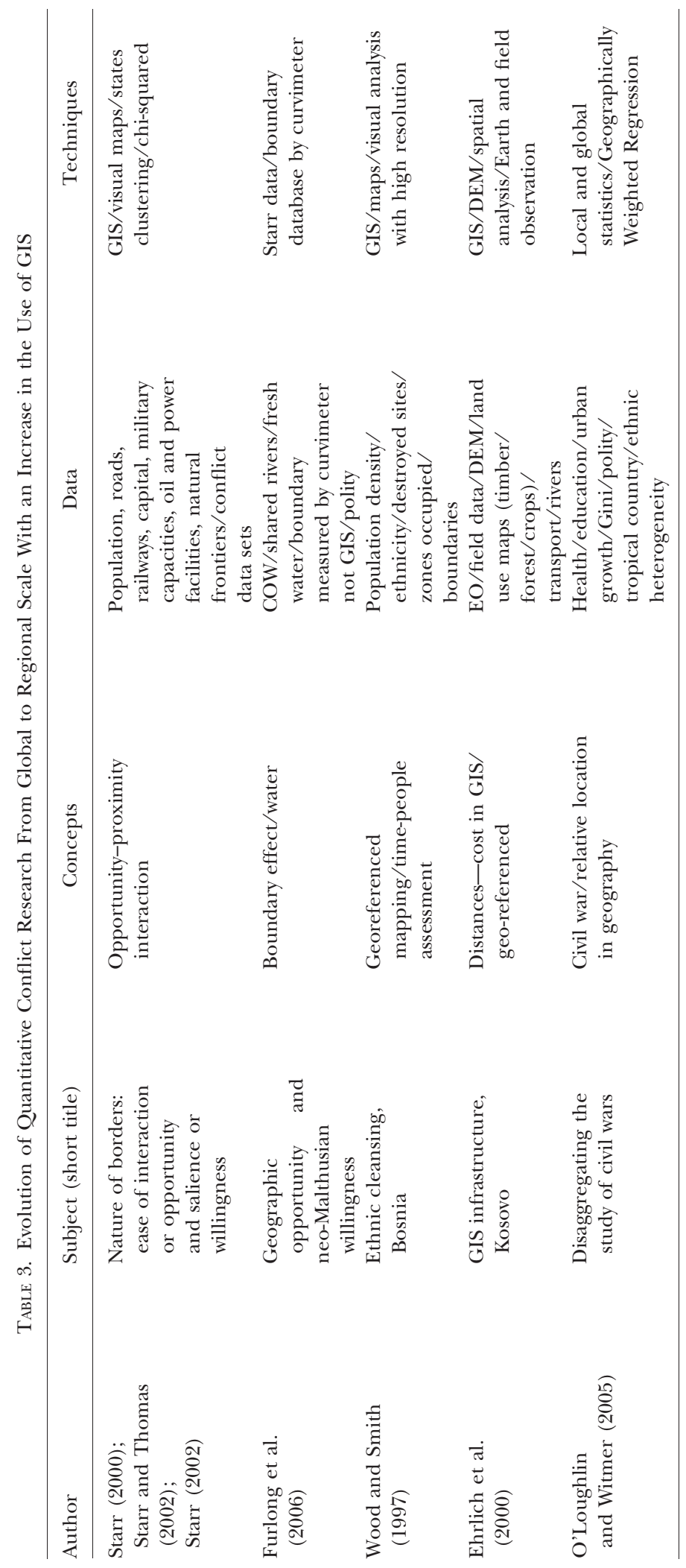




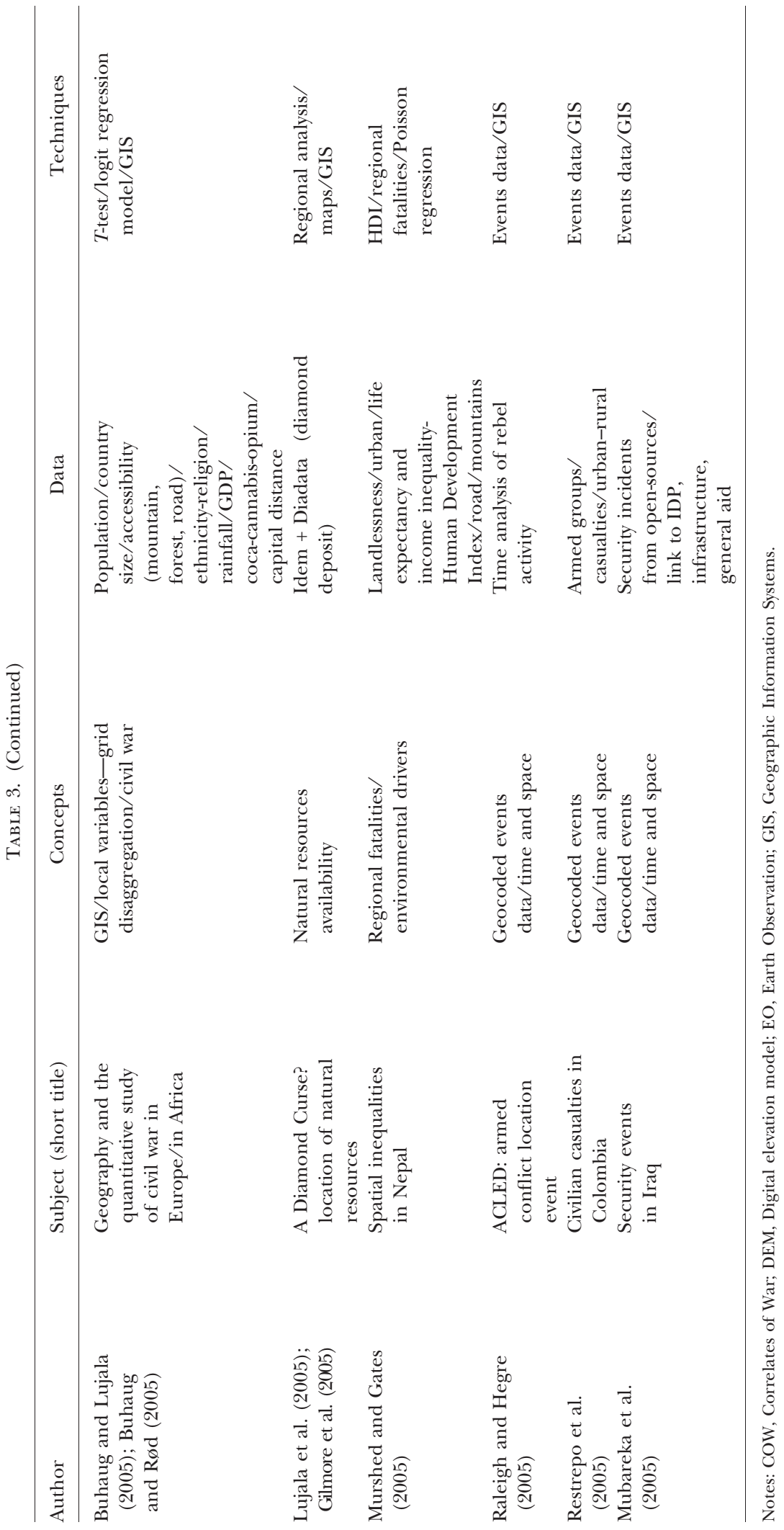


to sustain that cost. Lemke (1995) applied these concepts in conflict studies: he was able to annually modify Bueno de Mesquita and Lalman's (1992) power formula of number of miles per day. The relativity of distance is altered not only by the real changes in technology but also by the perception of mental distance (Schack 2000).

Proximity can then be expressed as a cost function. This cost varies as a function of the perception of distance by different actors, such as ethnic or political groups, and the type and nature of natural physical barriers, such as topographical obstacles or water bodies. This cost also varies as a function of comparable accessibility in terms of means of transport, such as roads, railways, ports. These measures are easily implemented into a GIS that combines different geographic data sets in a multicriteria and spatial model.

The fourth challenge in introducing "space" in a security model is stated by Starr (2003): "space should be integrated in conflict analysis without neglecting its temporal component." The capability to ask change-related questions requires a dynamic view of the relevant phenomena (Peuquet 1999). The best examples of integration of time and space dimensions are the diffusion models of Richardson (1960) or Hagerstand (1967) used by Most and Starr (1980), Gleditsch (2002), and Starr and Lindborg (2003). Applying a diffusion model in a GIS requires long time series that are not yet available (Buhaug 2003). The temporal information on conflict can be derived from historical maps or atlases. Use in a GIS would require the researcher to define the variable to be used, to define its spatial extent and to attach a proper semantic. Only then could the information be encoded through the digitization process. For example, a political boundary can be easily represented as a polygon. In the case of variables that change gradually, such as an ethnic or religious area, fuzzy representation would be required. This is typically carried out in a GIS using a raster data model that assigns a degree of fuzziness to a given grid cell. Combining space and time into a quantitative modeling framework would require considerable effort (Getis 1999).

\section{Data}

Most conflict studies address spatial/territorial issues at country level, using global data sets. Global statistical analysis of conflict can be supplemented by disaggregated, quantitative, geo-referenced data sets (Buhaug and Lujala 2005; Gilmore, Petter Gleditsch, Lujala, and Rød 2005; Lujala, Petter Gleditsch, and Gilmore 2005; Murshed and Gates 2005). Such data sets are available at subnational level. Table 3 presents a new strand of research that addresses conflict and border issues using increasingly GIS and spatial statistical methods. This strand of research is analyzed in detail in third and fourth sections. For each paper, Table 3 identifies data and techniques used to address spatial security concepts.

GIS can be used to build a spatial security model integrating variables used to describe sociopolitical phenomena. In this model, "entities" are things (events/processes) of the real world which are represented by "fields" or "objects" in the digital world (Mark 1999). Entities may be modeled spatially either as continuous functions varying along some surface (called "field") or as discrete entities with identifiable boundaries and identity (called "object"). The object/vector representations store geographic data in terms of points, lines and polygons (areas). Fields can be represented by "vector" approaches but are often represented by a "raster" structure (or regular grid cells, called pixels).

The socioeconomic representation of entities in a GIS requires the generation of spatial objects such as areas, points and lines, or of spatial fields such as regular grid cells. The defined objects can be labeled and described with attributes 
that are stored in a data base within a GIS. Attributes are descriptive. Spatial descriptive attributes are the name and specific characteristics of the real world entity. Spatial attributes are stored under vector or grid representation. Geographic records are then georeferenced. This model/projection makes a unique link between the object and its location on the Earth (coordinates).

\section{Statistical Data/Explanatory Variables}

Statistical indicators are the descriptive attributes associated with spatial objects. In territorial analysis, polygon vector features typically represent administrative units. Such units may be countries or subnational entities. Descriptive attributes of administrative units should represent driving forces of conflict. We propose to build an "integrated GIS security model," using as a starting point the driving forces from the sociopolitical studies reviewed in this paper (Table 4). There must be agreement about these indicators from both sides: GIS practitioners as well as academic human geographers. Unfortunately, spatial data for many driving forces are not yet available globally at the required scale and quality. Joint work by both communities of scientists is needed to build these data sets.

Table 4 lists spatial indicators of territory and border dimensions which are drawn from political geography and international relations studies. The indicators are proposed as explanatory variables for conflict escalation, severity or duration. The redefinition of security-shifting from state to human security-puts more emphasis on the "geographic indirect roots of historical conflicts" (Ullman 1983). Among these indirect roots, competition for territory and resources is clearly related to the ecological approach to conflict in environmental security studies (Bächler, Eaton, Eaton, Falkenmark, Ghosh, Isaac, et al. 1995; Homer-Dixon 1999). Hauge and Ellingsen (1998) integrated Malthusian variables in traditional statistical multivariate models of conflicts and concluded that their effects are significant but less important than political regime or military expenditure. Urdal (2005) recently tested resource scarcity as opposed to population growth explanations for conflict and did not find strong support for either hypothesis. Political conflict studies have considered natural resources as proxies for greed, grievance, opportunity and willingness in conflict (Collier and Hoeffler 2004; Ross 2004; Urdal 2005). Collier and Hoeffler (1998, 2004) use a proxy variable of natural resources extortion to measure the "opportunity" for setting up a rebel organization. For de Soysa (2002), Elbadawi and Sambanis (2002), and Fearon (2004), civil war prevalence is mostly explained by democracy and ethnic diversity. Ross (2004) finds evidence of the influence of oil, gemstones, timber, and drugs as resources that fuel conflicts.

\section{Vector Data}

Vector spatial objects are points, lines, or polygons. In security studies, vector data delineate territories, linear features, and other polygons. Territories are typically enclosed by both international and subnational boundaries, linear features include roads, railways, or river networks, and other polygons show the spatial extent of socioeconomic or environmental characteristics.

The cartographic representation of international boundaries is critical especially in disputed areas between two countries. Precise digitization of historical maps is required to digitally represent historical changes in territory and borders. Historical maps are available at varying scales, projections and levels of accuracy. These maps are not produced for quantitative analysis and are not usually available in digital form. The first point is especially true for small-scale maps. However, the information from historical maps can be turned into quantitative variables. This can be done through a process of standardization of the 
TABle 4. Main Quantitative and Spatial Indicators Identified as Drivers of Conflict

\begin{tabular}{|c|c|c|}
\hline \multirow{3}{*}{$\begin{array}{l}\text { Conflict location } \\
\text { and diffusion }\end{array}$} & Previous conflicts & Urdal (2005) \\
\hline & Regime type/level of democracy & $\begin{array}{l}\text { Urdal (2005); Collier and Hoeffler } \\
\text { (1998); Fearon and Laitin (2003) }\end{array}$ \\
\hline & $\begin{array}{l}\text { Geographic location of conflict } \\
\text { area by circular buffer around the } \\
\text { centroid }\end{array}$ & Buhaug and Lujala (2005) \\
\hline \multirow[t]{4}{*}{ Proximity } & $\begin{array}{l}\text { Relevant neighbors or contiguous } \\
\text { states }\end{array}$ & Richardson (1960); Diehl (1999) \\
\hline & Distance between capitals & Lemke (1995) \\
\hline & Distance between centroids & Richardson (1960); Vanzo (1999) \\
\hline & Minimum-distance threshold & Gleditsch and Ward (2001) \\
\hline \multirow[t]{7}{*}{ Border effect } & Number of shared borders & Wesley (1962) \\
\hline & Length of borders & Wesley (1962); Furlong et al. (2006) \\
\hline & $\begin{array}{l}\text { Type of border-homeland or } \\
\text { colonies }\end{array}$ & Starr and Thomas (2002) \\
\hline & $\begin{array}{l}\text { Relative cost in time necessary } \\
\text { to cross the border according to } \\
\text { topography along the border }\end{array}$ & Bueno de Mesquita and Lalman (1992) \\
\hline & $\begin{array}{l}\text { Technological changes of this } \\
\text { cost in time }\end{array}$ & Lemke (1995) \\
\hline & Salience or willingness & Senese (1999) \\
\hline & $\begin{array}{l}\text { Ease of interaction or opportunity } \\
\text { using a GIS approach* }\end{array}$ & Starr (2002) \\
\hline \multirow{4}{*}{$\begin{array}{l}\text { Population } \\
\text { distribution }\end{array}$} & Total number & Wils et al. (1998) \\
\hline & Population density & Hauge and Ellingsen (1998) \\
\hline & Population growth & Urdal (2005) \\
\hline & $\begin{array}{l}\text { Percentage of inhabited region that } \\
\text { can be related to the land cover }\end{array}$ & Buhaug and Rød (2005) \\
\hline \multirow[t]{6}{*}{ Inequality } & $\begin{array}{l}\text { Fractionalization (ethnic, } \\
\text { economic, and social) }\end{array}$ & $\begin{array}{l}\text { de Soysa (2002); Fearon and Laitin } \\
\text { (2003) }\end{array}$ \\
\hline & Urban population & de Soysa (2002); Homer-Dixon (1999) \\
\hline & $\begin{array}{l}\text { Fragmentation/polarization } \\
\text { (ethnic, economic, and social) }\end{array}$ & Buhaug and Gates (2002) \\
\hline & Poverty & Collier and Hoeffler (1998) \\
\hline & Infant mortality & Sen (1999) \\
\hline & Income inequality (Gini) & $\begin{array}{l}\text { Collier and Hoeffler (1998); Fearon } \\
\text { and Laitin (2003); Murshed and Gates } \\
(2005)\end{array}$ \\
\hline $\begin{array}{l}\text { External } \\
\text { Influences }\end{array}$ & International trade & Gleditsch (2002); de Soysa (2002) \\
\hline \multirow[t]{3}{*}{ Environment } & Cropland & Wils et al. (1998); Urdal (2005) \\
\hline & Land degradation & Hauge and Ellingsen (1998) \\
\hline & Roughness of the terrain $^{\dagger}$ & $\begin{array}{l}\text { Bueno de Mesquita and Lalman (1992); } \\
\text { Lemke (1995); Starr (2002); Fearon and } \\
\text { Laitin (2003) }\end{array}$ \\
\hline \multirow[t]{5}{*}{$\begin{array}{l}\text { Natural resource } \\
\text { availability }\end{array}$} & Primary commodities & $\begin{array}{l}\text { Collier and Hoeffler (2004); de Soysa } \\
\text { (2002); Elbadawi and Sambanis (2002) }\end{array}$ \\
\hline & $\begin{array}{l}\text { Presence of resources } \\
\text { including oil, gemstones, } \\
\text { illicit crops }\end{array}$ & Fearon and Laitin (2003)); Ross (2004) \\
\hline & Diamonds & Lujala et al. (2005) \\
\hline & Timber & Ross (2006) \\
\hline & Freshwater availability & $\begin{array}{l}\text { Hauge and Ellingsen (1998); Toset } \\
\text { et al. (2000); Furlong et al. (2006) }\end{array}$ \\
\hline
\end{tabular}

Notes: GIS, Geographic Information Systems; *Integrating road and railway networks, steepness of the terrain, a number of features such as population concentration and military or governmental infrastructures within a $4-\mathrm{km}$ buffer; 'Dismissed by other authors as nonrelevant for conflict research—Collier and Hoeffler 1998; Buhaug and Gates 2002. 
attributes, geometry and semantics for use in quantitative analysis. Gleditsch and Ward (2001) identified GIS as the technology to address this challenge. Furlong, Petter Gleditsch, and Hegre (2006) expressed interest in using GIS to improve the measurement of boundary length by traditional methods (curvimeter). However, few studies take into account the impact of linear geographic entities in conflicts, i.e. road density (Buhaug and Rød 2005).

GIS data model capabilities have mainly been used in two ways: to categorize border segments based on the length of a shared river (Toset et al. 2000) and to represent roads or railways as infrastructures crossing the border (Starr 2002). Integrated GIS databases can support humanitarian aid by precisely locating civil population needs in relation to road and river network information (Wood and Smith 1997) and by assessing accessibility of damaged regions (Ehrlich, Hansen, Louvrier, Hubbard, Richards, Reinartz, and Mehl 2000). All these studies have built precise data sets as the first step to geographically model instability.

While there is a clear spatial dimension in the territorial indicators integrated in regression models of conflicts, their precise extent by vector delineation is rarely available. These data can help to test the effect of territorial distribution of some indicators on conflict. At the scale of the Nepalese region, Murshed and Gates (2005) interestingly tested the spatial distribution of inequality (Human Development Indicator and landlessness) among subnational units and compared this with conflict, life expectancy, education, natural resource, or mountainous terrain variables. Recent studies geographically referenced some demographic and health data to investigate the spatial relationship between inequalities and conflicts in particular regions (Østby, Nordås, and Rød 2006).

\section{Raster Data (Grid Cells)}

The raster model represents field data in a continuous grid-based digital format. This type of digital data is mostly used in environmental studies. Raster data are used in particular in Earth observation (EO) where satellite images present a range of spectral values per pixel. Raster coded information is not yet extensively used in conflict research. However, the raster data model is widely used in sociopolitical studies using population figures (Deichmann and Eklundh 1991; Mubareka, Ehrlich, Bonn, and Kayitakire 2008). This wide usage is for a range of methodological reasons detailed below, and is related to the challenges of integrating space in a security model.

Raster models enable technical problems such as spatial heterogeneity to be overcome by using uniform units. When two data sets need to be compared, for example religious and ethnic distributions, the data can be provided in similar, regularly spaced grid cell format. The symmetrical grid cells are also easier to aggregate to test the issue of the MAUP. Population data are available at administrative level from censuses. These data are averages over areas that may include regions with very different population densities, especially where urban areas exist. Surface modeling allocates population and attributes, originally available at aerial units, to a fine scale in a regularly spaced grid. Population density can be indirectly estimated using open source information due to the specific geographic links between areas where humans are located, natural resource distribution and geographic conditions such as accessibility (Mubareka et al. 2008). Moreover, raster modeling provides the opportunity to apply fuzzy concepts. For example, ethnic or religious spatial distribution can be expressed in fuzzy form as a percentage of the value in space, making it possible to represent gradients that would be difficult to quantify otherwise.

A number of variables typically available in raster format are part of the list of explanatory variables defined in the section entitled Statistical Data/Explanatory Variables. Digital elevation models (DEM) obtained from laser, radar, or optical 
imagery can be used to derive measures of the "roughness of terrain." Gridded data sets of rainfall, land cover or natural resources are assembled using remote sensing data. Such gridded data sets can be used as quantitative proxies of cropland and land degradation. Gridded global population data sets in pixels of latitude/longitude units have been developed to address environmental issues (Tobler 1970; Deichmann and Eklundh 1991; Dobson, Bright, Coleman, Durfee, and Worley 2000; Sutton, Dar, Christopher, and Baugh 2001). Such gridded population data sets can be integrated in the GIS security model.

As civil wars occur within state boundaries, conflict events should be more precisely located within the country boundaries. Unfortunately, subnational data are only recently and partially available for a limited number of regions (Mubareka et al. 2005; Raleigh and Hegre 2005; Restrepo et al. 2005). EO and navigation technologies (Global Positioning Systems-GPS) can produce precise localizations. GIS can be used for delineation, database management, spatial analysis and cartographic display. Buhaug and Rød's (2005) solution to the conflict localization problem is a raster representation. Instead of the circle delineation which they used in the past (Buhaug and Lujala 2005), Buhaug and Rød (2005) defined uniform zones to represent the conflict. The $100 \times 100 \mathrm{~km}$ grid observation units can be easily related to other structural indicator data sets. Richardson (1960) had already proposed to map the number of people per homogenous compact cell through interpolation techniques. He broadly discussed the shape of the cell, describing the expected level of compactness in the territory expansion preferences or forms which facilitate communications and defense. Richardson finally chose the standard hexagonal cluster for mathematical reasons.

\section{Quantitative Methods}

Table 3 shows three fundamental methods or sets of methods to carry out quantitative analysis on security issues. These methods have emerged from the main quantitative conflict studies. The first is a set of statistical methods applied to data collected at national or subnational level; in these studies, the geographic units are international or subnational boundaries. The second is a set of spatial, mostly static GIS techniques of storage, analysis, and visualization. GIS spatial processing includes analysis of proximity, shape, size, buffering, and complex spatial models (fuzzy set membership functions) that are powerful tools to represent some territorial specificities. The third is system dynamics, to model spatiotemporal processes that include feedback and control mechanisms.

Each approach has its merits and, ideally, marrying these three approaches would increase the power of an ideal model. Integration of the three types of data presented in third section cannot be carried out without combining statistical and GIS techniques. The studies reviewed in Tables 2 and 3 of this paper have already proposed some combinations. Integration of the third method has not been carried out but may prove valuable in future security research to solve the problem of integrating space and time dimensions.

\section{Statistical Methods}

Studies aiming to find causal relationships between structural indicators and the occurrence and duration of armed conflict rely on regression analysis. These studies are usually carried out at the national level as they involve structural indicators that are collected on the country level. However, Buhaug and Lujala (2005) provided evidence of a better representation of conflict using subnational data. The spatial dimension is seldom taken into account, usually as a simple neighborhood indicator. Logistic models are most used to measure the 
frequency of security-related events (see e.g. Fearon 2003; Collier and Hoeffler 2004). Duration of security-related events is modeled using hazard models (Collier and Hoeffler 2004; De Rouen and Sobek 2004).

\section{GIS Models}

GIS provides the structure to build grid-based data as well as tools to integrate and overlay different data sets. A GIS model could predict and simulate "What if" scenarios that help to better understand reality. A number of territorial indicators can be calculated in a GIS. Such territorial indicators include geographic compactness (strategic element in territorial expansion), cash earnings from land use (generated by natural resource extraction), boundary segment lengths, number of border crossing points, natural features along the border, relative location, and distance (time taken to get from one location to the other/influence of transport technology improvement in the cost). Modeling these geographic concepts in an integrated model of conflict could provide insights into security issues.

Complex models including models of vulnerability attempt to combine climatic, economic and social risks to the population with coping strategies (Downing and Ludeke 2002). In the particular domain of border security, the permeability model measures the sustainability of crossing the border for an illegal migrant (Stephenne and Pesaresi 2006). This index is calculated using a multicriteria fuzzy decision support system integrating spatial data sets ranging from satellite remotely sensed data, land use, land cover, DEM, weather and environmental conditions, presence of population, infrastructure, and physical obstacles, to the presence of controlling border police.

\section{System Dynamics}

System dynamics could help deal with the space-time challenge identified previously. In the Malthusian (1798) approach, system dynamics models the interactions between population and resources (Meadows, Meadows, Randers, and Behrens 1972). The "environment and conflict project ENCOP"' (Bächler et al. 1995) and the University of Toronto group led by Homer-Dixon (Homer-Dixon 1999; Schwartz, Deligiannis, and Homer-Dixon 2000) represented quantitatively the mechanisms connecting environmental scarcity and violence using a neoMalthusian perspective (Halle et al. 2002). These authors tried to overcome the deterministic approach which was limited to a small set of quantitative variables by adopting a daring, holistic and dynamic approach that integrated the feedback effect of conflicts on the structural driving forces. Wils, Kamiya, and Choucri (1998) used four basic indicators: population size, purchasing power parity, land area as a natural resource and military expenditure.

A number of researchers have pinpointed shortcomings of the Malthusian approach. Gleditsch (1998) identifies problems in the work of Homer-Dixon (i.e. model complexity and missing factors), highlighting the definition of environmental security as one major issue. While the systemic approach has been criticized because of missing factors, the interest of this approach has been neglected. A combined GIS and system dynamics approach could be an interesting way to integrate space and time aspects into the explanatory framework put forward by sociopolitical scientists.

\section{Discussion: Geospatial Tool for Decision Making}

Geospatial products, and maps in particular, are powerful tools of communication between scientists and policymakers in security matters. Maps are used to display features of high relevance for security (Hay 2003). Even in digital format, 
maps act as visual communication tools that help in the interpretation of data and strengthen the message delivered through text (Denisov, Folgen, Rucevska, and Simonett 2005). EO has become a source of timely, frequently updated geospatial data over the whole world. For these reasons, EO data increases the usefulness of visual products for security purposes. When combined with field information, EO can work as a visual means for decision makers in negotiations (Wood and Smith 1997; Starr 2002). Satellite imagery is also used to assess damage after a conflict, to support needs assessments and reconstruction (Ehrlich et al. 2000). Very high resolution images and maps are even being progressively introduced as a participatory tool in local planning support (Lemma, Sliuzas, and Kuffer 2005).

Maps are, however, sometimes compiled from nonquantitative data neglecting standardized representation techniques. For this reason, the validity and the usefulness of the information contained in maps is sometimes questioned (Blake 2000). All maps are visual models with underlying assumptions. Whatever their utility in explaining a message, the political impact of maps is high and map producers need to be aware of this. Better communication between the two scientific communities of researchers can help to increase the relevance of geographic products for policymakers.

GIS provides an instrument to produce, test and simulate visually the security assumptions defined in sociopolitical studies. The cartographic functions of GIS can increase transparency in decision making. Thorough analysis of alternatives and clear presentation of results adds persuasive power in discussions of security issues (Wood and Milefsky 2002). New GIS interactive interfaces and tools, such as EDA, could be useful to communicate and coordinate decision making.

Nevertheless, to harness the potential of GIS, issues of data completeness and data quality need to be addressed. Using GIS in decision making requires weaknesses in data, and error propagation to be recognized and dealt with; it also requires uncertainty to be assessed and user needs to be evaluated. To respond to sociological critiques of GIS, data manipulation or virtual space methods as well as positivist epistemological assumptions have to be scrutinized (Schuurman 2000). For example, data sets need to be associated with appropriate geographic information to be geo-referenced.

\section{Conclusions and Future Research Agenda}

Security as an issue of territorial sovereignty has usually been associated with military defense forces and international conflicts. Military security is usually effective at the state level; while internal control over territory, such as that enforced by police forces, has to be effective at subnational level. Internal security includes issues such as ethnic conflict, resources monitoring and security of people. The change in the security paradigm from state to human security brings in environmental, socioeconomic, and demographic components that increase the interest of geographic studies at subnational level.

Geographic analysis of security issues is not new. Quantitative geographic analysis of security issues is. The quantitative geographic analysis of security issues has, by and large, concentrated on statistical explanations for international conflicts. However, there are few international conflicts today and many more civil wars. In the analysis of civil war, the data relating to conflict should be available at subnational level. This analysis also necessitates the use of spatial quantitative methods already common in geographic and environmental disciplines.

GIS can play an important part in building new concepts and models to address security issues. With globalization and regionalization processes, territories and identities need to be better defined and quantified. The geographic concepts that have been used in security research and reviewed in this paper 
include contiguity and bordering effect, distance or proximity, and diffusion in space and time. While their explanatory power has been described theoretically, the quantitative application of these concepts through GIS tools is an ongoing and interesting process.

GIS platforms should increasingly be used to integrate multidisciplinary data sets in addressing these geographic concepts. In this process, particular care must be taken both to assess data quality and to attach uncertainty measures to the variables represented by data. This new research agenda should involve political and social scientists as well as technology researchers in common methodological steps, such as:

- Collecting conflict data at subnational level. GPS as well as dynamic tracking techniques can improve accuracy in localizing conflict events.

- Developing methods to build gridded data sets of conflict events at spatial and time resolutions relevant for representing historical and recent disputes. Raster representation can help in localization, modeling, and integration with other data.

- Defining multicriteria structural indicators derived from various data sets, such as field information, EO imagery, and digital data sets. EO data can provide information on physical variables like topography, elevation, land cover, and natural resources. When structured into a GIS, these variables make it possible to measure distance, proximity, diffusion or accessibility and contested resources in relation to borders and population concentration (Table 4, above).

- Developing new spatial models to represent discontinuities in demographic, economic, and other processes that can provide insights into possible future disputes. For example, borders are permeable barriers through which illegal activities are carried out. Fuzzy analysis developed in statistical research can be applied to represent the behavior of actors.

- Carrying out methodological research to combine conflict indicators with structural indicator data sets in a dynamic quantitative and holistic approach. This approach could be inspired by system dynamics research. Modeling of security issues requires an in-depth understanding of the political and social context as well as the ability to develop spatial measures that can represent security issues.

- Using satellite imagery as a visual means in territorial and border disputes understanding. Satellite imagery and DEM were used operationally during the negotiations for the delineation of the international border between Bosnia and Herzegovina and Serbia (Wood and Smith 1997). Use of EO imagery and maps in political communication could be improved by better moderated interaction between disciplines and decision makers.

- Carrying out further research on monitoring tools and early warning systems, such work being still in its infancy. The frequent revisit time of EO can be an opportunity to monitor illegal activities-including illegal crops in conflict countries, illegal diamond extraction and illegal timber harvesting - which generate revenues for conflict parties.

These methodological steps can be carried out with a defined geographic focus by prioritizing some parts of the world. Conflict, especially civil strife, appears to occur between parties with certain characteristics described in sociopolitical studies. Each of these characteristics can be represented in the GIS model by specific data. Concrete examples are: (i) a long history of disputes, to be addressed using historical records of disputes; (ii) specific spatial patterns of 
territorial claims, to be addressed using subnational data on conflict events, visual and digital representation of borders; (iii) mountainous, forested or remote areas which are difficult to control for the central government, to be addressed using geographic models of remoteness, inaccessibility or digital maps of natural resources; and (iv) an ethnic or religious fragmentation pattern accompanied by high competition for resources, to be addressed using information on spatial distribution of ethnic or religious populations, and on the presence of natural resources such as oil or gas. The analysis and mapping of such characteristics in a common GIS model of security can prove very useful for security research.

Remote sensing can help in collecting information but it is in the GIS that the processes leading up to output are performed. These processes include data structuring, standardization, statistical and spatial analysis with modeling between layers. The GIS tool provides the opportunity for a participatory approach in both the physical and the social sciences, producing outputs that can be directly used by decision makers.

\section{References}

Ackleson, Jason. (2003) Directions in Border Security Research. The Social Science Journal $40(4): 573-581$.

Agnew, John, Katharyne Mitchell, and Gerard Toal. (2003) A Companion to Political Geography: Blackwell Companions to Geography. London: Blackwell Publishing.

Anselin, Luc. (1999) Interactive Techniques and Exploratory Data Analysis. In Geographical Information Systems, edited by Paul Longley, Michael Goodchild, David Maguire and David Rhind. New York: John Wiley and Sons.

Bächler, Günther, David J. Eaton, Joseph W. Eaton, Malin Falkenmark, Partha S. Ghosh, Jad IsAAC (1995) Environmental Crisis: Regional Conflicts and Ways of Cooperation, Vol. 14/1. Zurich: Center for Security Studies (CSS), ETH.

Blake, Gerald. (2000) Borderlands Under Stress: Some Global Perspectives. In Borderlands Under Stress, edited by Martin Pratt and Janet Allison Brown. London, UK: Kluwer Law International.

Boulding, Kenneth E. (1962) Conflict and Defense: A General Theory. New York: Harper and Row.

Bueno de Mesquita, Bruce, and David Lalman. (1992) War and Reason. New Haven, CT: Yale University Press.

Buhaug, Halvard. (2003) Spatial Data on Armed Intrastate Conflict. Paper presented at Joint Sessions of Workshops, Edinburgh, UK.

Buhaug, Halvard, and Scott Gates. (2002) The Geography of Civil Wars. Journal of Peace Research $39(4): 417-433$.

Buhaug, Halvard, and Jan Ketil Rød. (2005) Local Determinants of African Civil Wars, 19702001. Paper presented at 46th annual ISA Convention, Honolulu, HI.

Buhaug, Halvard, and Päivi Lujala. (2005) Accounting for Scale: Measuring Geography in Quantitative Studies of Civil War. Political Geography 24(4):399-418.

Burnley, Clementine, Nathalie Stephenne, and Merce Agüera-Cabo. (2008) Gender Dimensions in Geo-Spatial Security Research: Disciplinary Confrontations. Journal of International Women's Studies $9(4)$.

Collier, Paul, and Anke Hoeffler. (1998) On Economic Causes of Civil War. Oxford Economic Papers 50:563-573.

Collier, Paul, and Anke Hoeffler. (2004) Greed and Grievance in Civil War. Oxford Economic Papers 56:563-595.

Curry, Michael R. (1999) Rethinking Privacy in a Geocoded World. In Geographical Information Systems, edited by Paul Longley, Michael F. Goodchild, David Maguire and David Rhind. New York: John Wiley and Sons.

De Rouen Jr, Karl. R., and David Sobek. (2004) The Dynamics of Civil War Duration and Outcome. Journal of Peace Research 41(3):303-320.

Deichmann, Uwe, and Lars Eklundh. (1991) Global Digital Datasets for Land Degradation Studies: A Gis Approach. Nairobi, Kenya: United Nations Environment Program, Nairobi, Kenya. 
Del Rosso JR, Stephen. (1995) The Insecure State (What Future for the State?). Deadalus $124(2): 129-153$.

Denisov, Nickolai, Karen Folgen, Ieva Rucevska, and Otto Simonett. (2005) Impact II: Telling Good Stories. Arendal: GRID-Arendal/UNEP. 80.

Dienl, Paul F. (1999) A Road Map to War. Territorial Dimensions of International Conflict. Nashville and London: Vanderbilt University Press.

Dobson, Jerome E., Edward. A. Bright, Phillip R. Coleman, Richard C. Durfee, and Brian. A. Worley. (2000) Landscan: A Global Population Database for Estimating Populations at Risk. Photogrammetric Engineering and Remote Sensing 66(7):849-857.

Downing, Thomas E., And M. Ludeke. (2002) International Desertification: Social Geographies of Vulnerability and Adaptation. In Global Desertification: Do Humans Cause Deserts?, edited by James F. Reynolds and D.M Stafford Smith. Dahlem: Dahlem University Press.

Edwards, Thomas M. (2005) Information Geopolitics: Blurring the Lines of Sovereignty. In Holding the Line: Borders in a Global World, edited by Heather N. Nicol and Ian Townsend-Gault. Vancouver/Toronto: UBC press.

Ehrlich, Daniele, Christian Hansen, Christophe louvrier, Neil Hubbard, Tim Richards, Peter Reinartz, and Harald Mehl. (2000) Use of Satellite Imagery in the Set-up of a GIS to Support Reconstruction of Kosovo, Gis. Geo-Information-Systems 13:25-28.

Elbadawi, Ibrahim, and Nicholas Sambanis. (2002) How Much War Will We See?: Explaining the Prevalence of Civil War. Journal of Conflict Resolution 46:307-334.

Fearon, James D. (2003) Ethnic and Cultural Diversity by Country. Journal of Economic Growth $8(2): 195-222$.

Fearon, James D. (2004) Why Do Some Civil Wars Last So Much Longer Than Others? Journal of Peace Research 41(3):275-301.

Fearon, James D., And David D. Laitin. (2003) Ethnicity, Insurgency, and Civil War. American Political Science Review 97(1):75-90.

Fischer, Manfred M. (1999) Spatial Analysis: Retrospect and Prospect. In Geographical Information Systems, edited by Paul Longley, Michael Goodchild, David Maguire and David Rhind. New York: John Wiley and sons.

Foster, John Bellamy. (2006) The New Geopolitics of Empire [January]. Monthly Review, 57.

Furlong, Kathryn, Nils Petter Gleditsch, and Håvard Hegre. (2006) Geographic Opportunity and Neomalthusian Willingness: Boundaries, Shared Rivers, and Conflict. International Interactions 32(1):79-108.

Getis, Arthur. (1999) Spatial Statistics. In Geographical Information Systems, edited by Paul Longley, Michael F. Goodchild, David Maguire and David Rhind. New York: John Wiley and Sons.

Gilmore, Elisabeth, Nils Petter Gleditsch, Päivi Lujala, and Jan Ketil Rød. (2005) Conflict Diamonds: A New Dataset. Conflict Management and Peace Science 22(3):257-292.

Gleditsch, Nils Petter. (1998) Armed Conflict and the Environment : A Critique of the Literature. Journal of Peace Research 35(3):381-400.

Gleditsch, Kristian Skrede. (2002) All International Politics Is Local: The Diffusion of Conflict, Integration, and Democratization. Ann Arbor, MI: The University of Michigan Press.

Gleditsch, Kristian S., and Michael Ward. (2001) Measuring Space: A Minimum-Distance Database and Applications to International Studies. Journal of Peace Research 38(6):739-758.

Goertz, Gary, and Paul F. Dienl. (1992) Territorial Changes and International Conflict, Vol. 5: Studies in International Conflict. London and New York: Routledge.

HÄgerstrand, Torsten. (1967) Innovation diffusion as a spatial process, Chicago: University of Chicago Press.

Halle, Mark, Geoffrey Dabelko, Steve Lonergan, and Richard Matthew. (2002) State-of-the-Art Review on Environment, Security and Development Co-Operation. Paris: IUCN/OECD.

Hauge, Wenche, and Tanja Ellingsen. (1998) Beyond Environmental Scarcity: Causal Pathways to Conflict. Journal of Peace Research 35:3. 299-317.

Hay, William Anthony. (2003) Geopolitics of Europe. Orbis 47(2):295-310.

Homer-Dixon, Thomas. (1999) Environment, Scarcity, and Violence. Princeton: Princeton, University Press.

Huth, Paul K. (2000) Territorial Disputes and International Conflicts: Empirical Findings and Theoretical Explanations. In Borderlands Under Stress, edited by Martin Pratt and Janet Allison Brown. London, UK: Kluwer Law International.

Kwan, Mei-Po. (2002) Is GIS for Women? Reflections on the Critical Discourse in the 1990s. Gender, Place and Culture 9(3):271-279. 
Lemke, Douglas. (1995) The Tyranny of Distance: Redefining Relevant Dyads. International Interactions 17:113-126.

Lemma, Tsion, Richard Sliuzas, and Monika Kuffer. (2005) A Participatory Approach to Monitoring Slum Conditions. Paper presented at Mapping for change: International conference on participatory spatial information management and communication, Nairobi, Kenya.

Liu, Suxia, And Xuan Zhu. (2004) An Integrated GIS Approach to Accessibility Analysis. Transactions in GIS 8(1):45-62.

Longley, Paul, Michael Goodchild, David Maguire, and David Rhind, eds. (1999) Introduction. In Geographical Information Systems, edited by Paul Longley, Michael Goodchild, David Maguire and David Rhind. New York: John Wiley and Sons.

Lujala, Päivi, Nils Petter Gleditsch, and Elisabeth Gilmore. (2005) A Diamond Curse?: Civil War and a Lootable Resource. Journal of Conflict Resolution 49:538-562.

Malthus, Thomas. (1798) An Essay on the Principle of Population as Its Affects the Future Improvement of Society. London: J. Johnson.

Mamadouh, Virginie. (2005) Geography and War, Geographer and Peace. In The Geographies of War and Peace: From Death Camps to Diplomats, edited by Colin Flint. New York: Oxford University Press.

Mark, David M. (1999) Spatial Representation: A Cognitive View. In Geographical Information Systems, edited by Paul Longley, Michael F. Goodchild, David Maguire and David Rhind. New York: John Wiley and Sons.

Martin, Dave J. (1999) Spatial Representation: The Social Scientist's Perspective. In Geographical Information Systems, edited by Paul Longley, Michael F. Goodchild, David Maguire and David Rhind. New York: John Wiley and Sons.

Meadows, Donella H., Dennis L. Meadows, Jørgen Randers, and William W. Behrens iII. (1972) The Limits to Growth: Potomac Associates. New York: Universe Books.

Megoran, Nick. (2004) The Critical Geopolitics of the Uzbekistan-Kyrgyzstan Ferghana Valley Boundary Dispute, 1999-2000. Political Geography 23:731-764.

Most, B. A., and H. Starr. (1980) Diffusion, Reinforcement, Geopolitics, and the Spread of War. American Political Science Review 74:932-946.

Mubareka, Sarah, Delilah Al Khudhairy, Ferdinand Bonn, and Sami Aoun. (2005) Standardising and Mapping Open-Source Information for Crisis Regions: The Case of Post-Conflict Iraq. Disasters 29(3):237-254.

Mubareka, Sarah, Daniele Ehrlich, Ferdinand Bonn, and François Kayitakire. (2008) Settlement Location and Population Density Estimation in Rugged Terrain Using Information Derived From Landsat Etm and Srtm Data. International Journal of Remote Sensing 29(8):23392357.

Murshed, Mansoob, and Scott Gates. (2005) Spatial-Horizontal Inequality and the Maoist Insurgency in Nepal. Review of Development Economics 9(1):121-134.

Newman, David. (2000) Boundaries, Territory and Post Modernity: Towards Shared or Separated Spaces?. In In Borderlands Under Stress, edited by Martin Pratt and Janet Allison Brown. London: Kluwer Law International.

O'Loughlin, John. (2003) Spatial Analysis in Political Geography. In A Companion to Political Geography, edited by John Agnew, Katharyne Mitchell and Gerard Toal. Oxford: Blackwell Publishing.

O'Loughlin, John. (2005) The Political Geography of Conflict: Civil Wars in the Hegemonic Shadow. In The Geographies of War and Peace: From Death Camps to Diplomats, edited by Colin Flint. New York: Oxford University Press.

O'Loughlin, John, and Frank Witmer. (2005) Taking 'Geography' Seriously: Disaggregating the Study of Civil Wars. Paper presented at Disaggregating the study of civil war and transnational violence, University of California Institute of Global Conflict and Cooperation, La Jolla, CA.

Openshaw, Stan, and Paul J. Taylor. (1981) The Modifiable Areal Unit Problem. In Quantitative Geography: A British View, edited by Neil. Wrighley and Robert J. Bennet. London: Routledge.

Østby, Gudrun, Ragnhild Nord̊̊s, and Jan Ketil RøD. (2006) Regional Inequalities and Civil Conflict in 21 Sub-Saharan African Countries, 1986-2004. Paper presented at Polarization and Conflict, Nicosia, Cyprus.

PaAsi, Anssi. (2003) Territory. In A Companion to Political Geography, edited by John Agnew, Katharyne Mitchell and Gerard Toal. Oxford: Blackwell Publishing.

Peuquet, Donna J. (1999) Time in GIS and Geographical Database. In Geographical Information Systems, edited by Paul Longley, Michael F. Goodchild, David Maguire and David Rhind. New York: John Wiley and Sons. 
Pickles, John. (1995) Ground Truth: The Social Implications of Geographic Information Systems. New York: The Guilford Press.

Pullinger, Stephen S. (2006) EU Research and Innovation Policy and the Future of the Cfsp. Brussels: ISIS Europe.

Raleigh, Clionadh, and Håvard Hegre. (2005) Introducing Acled: An Armed Conflict Location and Event Dataset. Paper presented at Disaggregating the Study of Civil War and Transnational Violence, San Diego, CA.

Restrepo, Jorge A., Michael Spagat, Patrick Reanier, and Nicolás F. Suárez. (2005) Civilian Casualties in the Colombian Conflict: Georeferencing Human Security. Paper presented at Twenty-Fifth Annual ESRI International User Conference, San Diego, CA.

Richardson, Lewis F. (1960) Statistics of Deadly Quarrels. Pittsburg/Chicago: The Boxwood Press/Quadrangle books.

Ross, Michael L. (2004) How Does Natural Resource Wealth Influence Civil War? Evidence From 13 Cases. International Organization 58:35-67.

Ross, Michael L. (2006) A Closer Look at Oil, Diamonds, and Civil War. Annual Review of Political Science 9:265-300.

Schack, Michael. (2000) On the Multicontextual Character of Border Regions. In Borders, Regions and People, edited by Martin van der Velde and Henk van Houtem. London: Pion Ltd in association with the British \& Irish Section.

Schuurman, Nadine. (2000) Trouble in the Heartland: GIS and Its Critics in the 1990s. Progress in Human Geography 24(4):569-590.

Schuurman, Nadine, and Geraldine Pratt. (2002) Care of the Subject: Feminism and Critiques of GIS. Gender, Place and Culture 9(3):291-299.

Schwartz, Daniel M., Tom Deligiannis, and Thomas F. Homer-Dixon. (2000) The Environment and Violent Conflict : A Response to Gleditsch's Critique and Some Suggestions for Further Research. Environmental Change and Security Project Report 6:77-94.

Sen, Amartya. (1999) Development as Freedom. New York: Alfred A. Knopf.

Senese, Paul D. (1999) Geographical Proximity and Issue Salience: Their Effetcs on the Escalation of Militarized Interstate Conflict. In A Road Map to War. Territorial Dimensions of International Conflict, edited by Paul F. Diehl. Nashville and London: Vanderbilt University Press.

DE Soysa, Indra. (2002) Ecoviolence: Shrinking Pie or Honey Pot? Global Environmental Politics 2(4):1-36.

Starr, Harvey. (2000) Using Geographical Information Systems to Revisit Enduring Rivalries: The Case of Israel. Geopolitics 5(1):37-56.

Starr, Harvey. (2002) Opportunity, Willingness and Geographic Information Systems (GIS): Reconceptualizing Borders in International Relations. Political Geography 21 (2):243-261.

Starr, Harvey. (2003) The Power of Place and the Future of Spatial Analysis in the Study of Conflict. Conflict Management and Peace Science 20(1):1-20.

Starr, Harvey, and Benjamin A. Most. (1976) The Substance and Study of Borders in International Relations Research. International Studies Quarterly 20:581-620.

Starr, Harvey, and Dale G. Thomas. (2002) The 'Nature' of Contiguous Borders: Ease of Interaction, Salience, and the Analysis of Crisis. International Interactions 28:213-235.

Starr, Harvey, and Christina Lindborg. (2003) Democratic Dominoes Revisited. Journal of Conflict Resolution 47(4):490-519.

Stephenne, Nathalie, and Martino Pesaresi. (2006) Spatial Permeability Model at the European Union Land Border. 61. Luxembourg: European Commission/DG-JRC/IPSC.

Sutton, Paul C., Roberts Dar, Elvidge Christopher, and Kimberly Baugh. (2001) Census From Heaven: An Estimate of the Global Human Population Using Night-Time Satellite Imagery. International Journal of Remote Sensing 22(16):3061-3076.

Tir, Jaroslav, and Paul F. Diehl. (2002) Geographic Dimensions of Enduring Rivalries. Political Geography 21(2):263-286.

Tobler, Waldo R. (1970) A Computer Movie: Simulation of Population Change in the Detroit Region. Economic Geography 46:234-240.

Toset, Hans Petter Wollebek, Nils Petter Gleditsch, and Håvard Hegre. (2000) Shared Rivers and Interstate Conflict. Political Geography 19(8):971-996.

Ullman, Richard H. (1983) Redefining Security. International Security 8(1):129-153.

Urdal, Henrik. (2005) People Vs. Malthus: Population Pressure, Environmental Degradation, and Armed Conflict Revisited. Journal of Peace Research 42(4):417-434. 
Vanzo, John P.F. (1999) Border Configuration and Conflict: Geographical Compactness as a Territorial Ambition of States. In A Road Map to War. Territorial Dimensions of International Conflict, edited by Paul F. Diehl. Nashville and London: Vanderbilt University Press.

Vasquez, John A. (1993) The War Puzzle, Vol. 27. Cambridge Studies in International Relations. Cambridge: Cambridge University Press.

Wesley, James Paul. (1962) Frequency of Wars and Geographical Opportunity. Journal of Conflict Resolution 6:4. 387-89.

Wils, Annababette, Matilde Kamiya, and Nazli Choucri. (1998) Threats to Sustainability: Simulating Conflict Within and Between Nations. System Dynamics Review 14(2-3):129-162.

Wood, William B., and Ray Milefsky. (2002) Gis as a Tool for Territorial Analysis and Negotiations. In The Razor's Edge, edited by Clive Schofield, David Newman, Alasdair Drysdale and Janet Allison Brown. London, UK: Kluwer Law International.

Wood, William B., AND D.G. Smith. (1997) Mapping War Crimes: GIS Analyzes Ethnic Cleansing Practices in Bosnia [September]. GIS World.

Zipf, George Kingsley. (1946) The P1p2/D Hypothesis: On the Intercity Movement of Persons. American Sociological Review 11:677-686. 